\title{
TRABALHO BANCÁRIO E ASSÉDIO MORAL: ALGUMAS CONSIDERAÇÕES A PARTIR DA ANÁLISE DA JURISPRUDÊNCIA DO TRT-MG
}

\author{
BANKING SECTOR AND MORAL HARASSMENT: SOME CONSIDERATIONS FROM \\ THE ANALYSIS OF JURISPRUDENCE OF TRT-MG
}

\author{
Luciano dos Santos Diniz (CEFET-MG) ${ }^{1}$ \\ Isabela Ferreira Henriques (CEFET-MG) ${ }^{2}$ \\ Paulo Fernandes Sanches Junior (CEFET-MG) ${ }^{3}$
}

\section{RESUMO}

No atual contexto de restruturação produtiva, em que se observa a perda de direitos trabalhistas, a intensificação do ritmo laboral e o incentivo ao individualismo, nota-se a paulatina deterioração das relações laborais. A competição desmedida entre trabalhadores e a valorização da produtividade individual favorece a ocorrência de assédio moral no trabalho. Este artigo buscou identificar as práticas mais comuns de assédio moral sofridas por empregados do setor bancário de Minas Gerais, por meio da análise da jurisprudência do Tribunal Regional do Trabalho da $3^{\text {a }}$ Região, correspondente ao primeiro semestre de 2018. Para tanto, foram utilizadas pesquisa bibliográfica, documental e de levantamento. Com base nos 147 acórdãos examinados, os três bancos que mais figuraram como réus foram: Bradesco, Itaú e Banco do Brasil. Os resultados da pesquisa apontam que cobranças abusivas de metas, situações vexatórias e ameaças de demissão foram as condutas de assédio mais usuais nas reclamatórias trabalhistas examinadas.

Palavras-chave: assédio moral, instituições financeiras, jurisprudência; indenização; TRT-MG.

\begin{abstract}
In the current context of productive restructuring, in which the loss of labor rights, the intensification of the labor and the incentive to individualism are observed, the gradual deterioration of labor relations is noted. The excessive competition between workers and the enhancement of individual productivity favors the occurrence of moral harassment in the workplace. This article aims to identify common practices of moral harassment suffered by employees in the banking sector of Minas Gerais, based on the analysis of the jurisprudence of the Regional Labor Court of the 3rd Region, corresponding to the first semester of 2018. Bibliographic, documentary and survey research were used. Based on the 147 judgments examined, the three banks that most appeared as defendants were: Bradesco, Itaú and Banco do Brasil. The results show that abusive demands for goals, vexatious situations and dismissal threats were the most common harassment behaviors in the labor claims examined.
\end{abstract}

Keywords: moral harassment, banking sector, jurisprudence; legal indemnity, TRT-MG.

\footnotetext{
1 Doutor em Ciências Sociais, professor adjunto III do Centro Federal de Educação Tecnológica de Minas Gerais (CEFET-MG).E-mail: lucianodiniz@dcsa.cefetmg.br.

2 Bacharel em Administração no Centro Federal de Educação Tecnológica de Minas Gerais (CEFET-MG). E-mail: isabelafhenriques@hotmail.com.

3 Doutor em Engenharia Civil, professor associado III do Centro Federal de Educação Tecnológica de Minas Gerais (CEFET-MG).E-mail: sanches@dcsa.cefetmg.br.
} 


\section{INTRODUÇÃO}

Em um contexto de restruturação produtiva no qual se observa o crescimento das taxas de desemprego, a perda de direitos trabalhistas, a intensificação do ritmo laboral e o incentivo ao individualismo, nota-se simultaneamente a precarização das condições e das relações de trabalho (ANTUNES, 2014; 2018; 2020).

O quadro de superexploração da força de trabalho - com a competição desmedida entre trabalhadores, a acentuada preocupação com a produção, o desprezo pelo trabalho em equipe e a materialização cada vez mais evidente das relações humanas - cria um ambiente hostil extremamente favorável a práticas caracterizadoras do assédio moral (PAROSKI, 2006). Enquanto expressão do gênero "violência no trabalho", o assédio moral constitui-se como um fenômeno social que minimiza, desvaloriza e agride o trabalhador, causando-lhe danos à personalidade e à dignidade, podendo levar a somatizações que degradam sua higidez física e mental (SOARES; VILLELA, 2012).

No setor bancário, as mudanças advindas da reestruturação produtiva resultaram, dentre outras medidas, no prolongamento da jornada de trabalho; na imposição de variadas metas e forte pressão para efetivo cumprimento delas; além de um rígido controle sobre o tempo de trabalho dos funcionários. Como consequência, há intensificação das queixas de assédio moral no ambiente laboral, com repercussões negativas na saúde e na qualidade de vida dos bancários, como a depressão e o suicídio (MACIEL et al., 2007; SOARES, VILLELA, 2012).

A resistência das organizações em seguir as normas de segurança e saúde do trabalho, bem como a dificuldade na implementação de políticas públicas voltadas para esses aspectos, tem levado ao fracasso de medidas preventivas e resultado em um expressivo número de reclamatórias trabalhistas, objetivando à reparação por danos advindos de condutas configuradoras do assédio moral.

O estudo do assédio moral no setor bancário se justifica em razão da realidade econômica brasileira e pelas recentes mudanças ocorridas no ordenamento juslaboral, cuja flexibilização vindicada pelo capitalismo neoliberal, a fim de compatibilizar a relação entre o trabalho e o capital, tem promovido a precarização, a terceirização e o desemprego. O tema ganha ainda mais relevância em virtude de a reforma trabalhista (Lei $n^{\circ} 13.467 / 2017$ ) estabelecer o salário contratual do ofendido como base para a fixação da reparação por danos morais. A limitação dos patamares indenizatórios é, inclusive, objeto de três ações diretas de inconstitucionalidade ${ }^{4}$ junto ao Supremo Tribunal Federal (STF), dada à afronta a preceitos protetivos do trabalho, bem como à isonomia e à dignidade humana.

Nesse contexto, o presente artigo buscou identificar as práticas mais comuns de assédio moral sofridas por empregados do setor bancário de Minas Gerais, por meio da análise da jurisprudência do Tribunal Regional do Trabalho da $3^{\text {a }}$ Região (TRT-MG), correspondente ao período compreendido entre janeiro e junho de 2018 .

Trata-se de um estudo de abordagem qualitativa e natureza descritiva, no qual foram utilizadas pesquisas bibliográfica, documental e de levantamento; cujo detalhamento da metodologia, bem como das técnicas de pesquisa adotadas, é evidenciado na seção VI.

Para cumprir o objetivo proposto na pesquisa, fez-se necessário, primeiramente, delimitar o conceito de assédio moral no trabalho e os elementos que o caracterizam; o regime de reparação por dano moral aplicável às relações laborais; para então abordar as

4 AADIn 5870, pela Associação Nacional dos Magistrados da Justiça do Trabalho; a ADIn 6082, pela Confederação Nacional dos Trabalhadores na Indústria - CNTI; e, a ADIn 6069, pelo Conselho Federal da OAB. 
queixas mais comuns de assédio no setor bancário a partir da jurisprudência; bem como os elementos utilizados pelos julgadores para fundamentar a procedência ou não das reclamatórias trabalhistas ajuizadas.

\section{ELEMENTOS PARA A CARACTERIZAÇÃO DO ASSÉDIO MORAL}

Segundo Hirigoyen (2002), assédio moral deve ser compreendido como qualquer conduta abusiva, que pode se manifestar, principalmente, por meio de comportamentos, falas, gestos e escritos e que possa trazer danos à personalidade, à dignidade ou à integridade física ou psíquica de uma pessoa, além de colocar em risco seu emprego ou deteriorar o ambiente de trabalho. No mesmo sentido, Araújo aduz que o assédio moral decorre de

uma conduta abusiva, intencional, frequente e repetida, que ocorre no ambiente de trabalho e que visa diminuir, humilhar, vexar, constranger, desqualificar e demolir psiquicamente um indivíduo ou um grupo, degradando as suas condições de trabalho, atingindo a sua dignidade e colocando em risco a sua integridade pessoal e profissional. (ARAÚJO, 2007a, p. 37).

As condutas abusivas, para Hirigoyen (2002), são distribuídas em quatro subgrupos de ações, sendo elas: (i) deterioração proposital das condições de trabalho; (ii) isolamento e recusa de comunicação; (iii) atentado contra a dignidade e, por fim, (iv) violência verbal física ou sexual, conforme se infere do Quadro 1.

\section{QUADRO 1 - GRUPOS DE CONDUTAS ABUSIVAS}

\begin{tabular}{|c|c|}
\hline Subgrupos & Ações abusivas \\
\hline $\begin{array}{l}\text { Deterioração pro- } \\
\text { posital das condi- } \\
\text { ções de trabalho }\end{array}$ & $\begin{array}{l}\text { Retirar a autonomia do trabalhador; não lhe transmitir as informações úteis para } \\
\text { realização de tarefas; contestar sistematicamente todas as suas decisões; criticar seu } \\
\text { trabalho de forma injusta ou exagerada; privá-lo do acesso aos instrumentos de traba- } \\
\text { lho; retirar o trabalho que normalmente lhe compete; dar-lhe permanentemente novas } \\
\text { tarefas; atribuir propositalmente e sistematicamente tarefas inferiores ou superiores às } \\
\text { suas competências; pressioná-lo para que não faça valer seus direitos; agir de modo a } \\
\text { impedir a obtenção de promoção; atribuir-lhe tarefas incompatíveis com sua saúde ou } \\
\text { consideradas perigosas; causar danos em seu local de trabalho, dar-lhe deliberadamente } \\
\text { instruções impossíveis de executar; induzi-lo ao erro. }\end{array}$ \\
\hline
\end{tabular}

Isolamento e recusa de comunicação
Interromper constantemente a vítima; cercear sua comunicação com superiores hierárquicos ou colegas; restringir a comunicação com a vítima somente por escrito; recusa de contato, até mesmo visual; ignorar sua presença; isolá-la no espaço de trabalho.

Utilizar insinuações desdenhosas para qualificar a vítima; fazer gestos de desprezo diante dela; desacreditá-la diante dos colegas, superiores ou subordinados; espalhar Atentado contra a rumores a seu respeito; atribuir-lhe problemas psicológicos; zombar de seus aspectos dignidade físicos, de suas origens e de sua nacionalidade; criticar sua vida privada, suas crenças religiosas e convicções políticas; atribuir-lhe tarefas humilhantes; injuriá-la com termos obscenos ou degradantes.

Ameaçar; agredir fisicamente; fechar a porta na cara; falar com o indivíduo aos gritos;

Violência verbal, invadir a vida privada da vítima com ligações telefônicas ou cartas; espioná-la em seu física ou sexual domicílio; fazer estragos em seus bens materiais; assediá-la ou agredi-la sexualmente; ignorar problemas de saúde da vítima.

Fonte: Elaborado pelos autores com base em Hirigoyen (2002). 
Dentre os critérios frequentemente utilizados para a identificação do assédio moral no trabalho, destaca-se a intencionalidade de prejudicar, a repetição de comportamentos hostis e a durabilidade do assédio (ARAÚJO, 2007b; SOBOLL, 2008; BATTISTELLI; AMAZARRAY; KOLLER, 2011; GLINA; SOBOLL, 2012). Para Einarsen et al. (2011), de fato, o assédio moral não é um evento isolado, diferenciando-se do dano moral nesse sentido, uma vez que se caracteriza como uma prática contínua, sendo que de forma geral há um entendimento entre pesquisadores que o assédio se configura mais como uma questão de meses e anos do que de dias e semanas. Para Alkimin (2009), o assédio deve ser aquela conduta degradante e humilhante praticada de forma reiterada e sistemática, ou seja, com certa frequência, visando desestabilizar a vítima, afetando sua dignidade e seus direitos de personalidade.

Glina e Soboll (2012) e Soboll, Miara e Moscalewsky (2017) entendem, contudo, que a intencionalidade não pode ser considerada como um elemento caracterizador do assédio moral, pois a intenção do assediador de atingir sua dignidade, ou de excluir a pessoa assediada do trabalho, pode ou não estar presente. Além do mais, as autoras ressaltam que a intencionalidade é um elemento de difícil comprovação, além de sua avaliação ser demasiadamente subjetiva.

Hirigoyen (2002) alerta para a possibilidade de que o uso inadequado do termo assédio pode levar à sua banalização e consequente descrença da problemática vivenciada por diversos trabalhadores. Nessa medida, Silva (2011) esclarece que agressões pontuais; más condições de trabalho, quando não impostas a fim de atingir o indivíduo e afastá-lo do ambiente laboral; estresse no caso de não ter sido provocado de forma intencional; situações conflituosas e, por fim, legítimo exercício do poder de comando não se enquadram como assédio moral. Logo, agressões pontuais que decorrem do estresse, do mau humor, da má educação ou da impaciência, às quais cotidianamente os trabalhadores estão expostos no ambiente laboral, não constituem um problema. O que as diferencia do assédio moral são a habitualidade, a insistência e a sistematicidade, com vistas a gerar na vítima sentimentos de descrédito e humilhação (HIRIGOYEN, 2002; SOARES, VILLELA, 2012).

Ressalta-se que os casos de assédio moral não se restringem às ações de cunho interpessoal, alocando-o como uma manifestação de caráter individual, enquanto uma "perversão do ego" do assediador (BATTISTELLI; AMAZARRAY; KOLLER, 2011). Autores como Araújo (2007b), Soboll (2008), Battistelli, Amazarray, Koller (2011), Glina e Soboll (2012), Soboll, Miara e Moscalewsky (2017) e Soboll (2017) discutem a ocorrência do fenômeno por meio da combinação de uma série de elementos que favorecem a disseminação de práticas abusivas no trabalho. Para eles, fatores ligados (i) à personalidade de agressores e vítimas; (ii) às especificidades das relações interpessoais; (iii) às mudanças socioeconômicas e (iv) à conjuntura organizacional devem ser considerados quando da análise das violências oriundas do ambiente laboral.

\section{ASSÉDIO MORAL E A ORGANIZAÇÃO}

A organização tem função determinante em relação ao assédio moral. Conforme Freitas, Heloani e Barreto, "o assédio moral ocorre porque encontra um terreno fértil e tende a se cristalizar como uma prática, pois os seus atores não encontram maiores resistências organizacionais ou reprovações" (2008, p. 39). As políticas organizacionais, por vezes, permitem e até recompensam o assédio moral, já que a empresa pode se beneficiar desse tipo de comportamento. A instrumentalização pela organização de humilhações e constrangimentos impingidos à vítima, visando controlar a subjetividade do trabalhador, denota o chamado "gerenciamento de recursos humanos por outros meios" (GLINA; SOBOLL, 2012, p. 276). 
A cultura da organização é responsável por definir a maneira como os indivíduos interagem dentro daquele contexto organizacional, apontando os comportamentos adequados e aceitos. Assim, nos ambientes em que vigora uma cultura organizacional de estímulo à competição exacerbada e ao individualismo, o relacionamento interpessoal se torna desrespeitoso, favorecendo a flexibilização da conduta moral e o abuso intencional entre os indivíduos (FREITAS, 2007). Nesse aspecto, o assédio moral organizacional se destinaria à intensificação da produtividade - com sobrecarga de trabalho, sob forte pressão -, e ao reforço do controle, da disciplina e da submissão do trabalhador frente ao poder diretivo da organização (ARAÚJO, 2007a; 2007b; SOBOLL, 2008; BATTISTELLI; AMAZARRAY; KOLLER, 2011; SOARES; VILLELA, 2012; ANTUNES; PRAUN, 2015; SOBOLL; MIARA; MOSCALEWSKY, 2017; SOBOLL, 2017; ANTUNES, 2014; 2018; 2020).

Para Cavalcante e Jorge Neto,

o individualismo exacerbado reduz as relações afetivas e sociais no local de trabalho, gerando uma série de atritos, não só entre as chefias e os subordinados, como também entre os próprios subordinados. O implemento de metas, sem critérios de bom-senso ou de razoabilidade, gera uma constante opressão no ambiente de trabalho, com a sua transmissão para os gerentes, líderes, encarregados e os demais trabalhadores que compõem um determinado grupo de trabalho. As consequências dessas tensões (= pressões) repercutem na vida cotidiana do trabalhador, com sérias interferências na sua qualidade de vida, gerando desajustes sociais e transtornos psicológicos. (2005, p. 1-2).

A estrutura organizacional e as políticas de desempenho comumente estabelecidas pelos empregadores não comportam profissionais que estejam em desacordo com o perfil de trabalhador normalmente exigido pelas empresas. Logo, aqueles que apresentam limitações na sua produtividade, que padeçam de incapacidades laborativas após licenças de saúde ou que componham grupos socialmente discriminados (mulheres, negros, homossexuais, deficientes físicos) são mais suscetíveis a serem vítimas de assédio moral (BATTISTELLI; AMAZARRAY; KOLLER, 2011). O ambiente de trabalho hostil acaba resultando na saída da vítima, seja por meio da dispensa, seja pelo pedido de demissão, seja até mesmo em razão de sua aposentadoria por invalidez (ARAÚJO, 2007b; SOBOLL; MIARA; MOSCALEWSKY, 2017).

As externalidades negativas decorrentes do assédio moral, além das consequências nefastas à vida pessoal, profissional, familiar, à saúde física e mental da vítima, acarretam prejuízos também para as organizações, principalmente no que diz respeito ao aumento dos custos decorrentes do afastamento de pessoal por doenças e acidentes de trabalho; absenteísmo; rotatividade de funcionários; queda de produtividade consequente da desmotivação; perda de equipamentos pela desconcentração; além de custos judiciais gerados por indenizações de cunho moral e/ou patrimonial (GUEDES, 2006; FREITAS, 2007).

Logo, por serem as organizações as responsáveis por determinar as estruturas, os padrões de relações de trabalho e o que por ela é valorizado, conclui-se que as empresas são detentoras de mecanismos que podem facilitar ou dificultar a ocorrência do assédio moral (FREITAS, 2007).

O assédio moral frequentemente é relacionado às relações entre superiores e subordinados de uma organização. Contudo, conforme esclarece Araújo (2007a), o assédio moral pode ser: (i) oriundo do superior hierárquico da vítima, denominado assédio vertical descendente; (ii) praticado pelos próprios colegas de trabalho, identificado como assédio moral horizontal; e, por fim, e mais raro; (iii) vertical ascendente, quando um ou mais subordinados 
praticam assédio moral em relação ao seu superior hierárquico. Stadler (2008) elucida que dentro de uma organização qualquer indivíduo pode ser vítima ou agressor, inclusive concomitantemente. Nesse aspecto, Araújo ressalta que

\begin{abstract}
Longe do que pode fazer crer, o assédio moral organizacional não se restringe à modalidade do assédio moral vertical descendente, essa situação decorre da pulverização do exercício do poder em todos os níveis da empresa. Os colaboradores, se colocados diante de um membro da equipe improdutivo ou de baixa produtividade, podem assumir condutas abusivas com a finalidade de pressionar o dissidente a assumir os níveis de produção e qualidade exigidos pela administração. O grupo de trabalhadores é levado a se colocar na posição do verdadeiro empreendedor, crendo-se realmente participante das decisões da empresa. (2007a, p. 85).
\end{abstract}

Como tais comportamentos estão pautados pelo lucro desmedido, pela competitividade e pelo estabelecimento de metas abusivas, a associação do assédio às relações de cunho interpessoal pode ser relativizada, já que a cultura e as políticas organizacionais tendem a contribuir para a disseminação de práticas associadas ao assédio moral. Assim, em um ambiente em que todos, gestores ou não, estão usualmente submetidos a pressões e estratégias abusivas, verifica-se o estímulo, direto ou indireto da organização, à violência psicológica no trabalho (BATTISTELLI; AMAZARRAY; KOLLER, 2011). Ao estabelecer os contornos e a extensão do assédio moral organizacional, Araújo (2007b) destaca que

A identificação do assédio moral organizacional, em que o assédio individual nada mais é que uma expressão parcial, rompe o tratamento psicológico do problema e devolve a discussão sobre as condições de trabalho e os mecanismos de gestão de mão de obra aos espaços coletivos. A sua visualização explica a inércia dos setores internos da empresa diante das denúncias individuais e a desconfiança dos trabalhadores em relação a esses órgãos. Permite-nos também averiguar a eficácia dos mecanismos internos de prevenção difundidos no mundo, tais como: códigos de ética, observatórios de violência, cursos de autodefesa para trabalhadores e a mediação. (ARAÚJO, 2007b, p. 214).

Pautado inicialmente nas relações interpessoais entre vítima-agressor (abordagem tradicional), a percepção atual é a de que o assédio moral tem origem na forma de organização do trabalho e da sociedade (abordagem psicossocial), associado a fatores individuais e às interações humanas (SOBOLL, 2017). Para esse mesmo autor, o assédio, "agora disseminado tanto nos discursos como nas práticas, é só uma parte da violência naturalizada do cotidiano do trabalho em nossa sociedade, construído historicamente e sustentado coletivamente" (2017, p. 11).

Seguindo essa perspectiva, Antunes e Praun (2015) identificam o assédio moral como fenômeno social atrelado ao ambiente organizacional e às mudanças socioeconômicas da contemporaneidade. Para eles,

espaços de trabalho propulsores de altos índices de desempenho e produtividade, estruturados com base nas exigências que cada vez mais extrapolam a capacidade física e mental humana em suportá-las, não conseguem manter-se senão por meio de diferentes e sofisticados mecanismos de controle e coerção. O assédio moral é parte dessa engrenagem. (ANTUNES; PRAUN, 2015, p. 419-420).

Desse modo, embora atos de violência no trabalho sejam anteriores ao processo de reorganização do trabalho e da produção verificada nas últimas décadas do século XX, é no contexto do capitalismo neoliberal, denominado de "acumulação flexível" (HARVEY, 2011), 
que a prática de assédio moral assume novo significado e se dissemina no mundo do trabalho (ANTUNES, PRAUN, 2015).

\title{
4. DIREITO DO TRABALHO E A REFORMA TRABALHISTA
}

O Direito do Trabalho visa assegurar os direitos fundamentais e as garantias mínimas de dignidade no trabalho. A esse respeito, Bussinguer (2008) declara que o papel do Direito do Trabalho é assegurar que a lógica da dignidade impere, e não a lógica do preço. Para isso, é necessário assegurar que o trabalhador seja visto como ser humano, e não como uma mera engrenagem da produção.

Sarlet, Marinoni e Mitidiero conceituam a dignidade da pessoa humana como:

\begin{abstract}
Aqualidade intrínseca e distintiva reconhecida em cada ser humano que o faz merecedor do mesmo respeito e consideração por parte do Estado e da comunidade, implicando, neste sentido, um complexo de direitos e deveres fundamentais que assegurem a pessoa tanto contra todo e qualquer ato de cunho degradante e desumano como venham a lhe garantir as condições existenciais mínimas para uma vida saudável, além de propiciar e promover sua participação ativa e responsável nos destinos da própria existência e da vida em comunhão com os demais seres humanos. (2012, p. 37).
\end{abstract}

Barros (2008) destaca a importância de reconhecer o valor da integridade de todos os indivíduos, tendo em vista a particularidade de cada ser humano e as transformações de personalidade e conduta decorrentes de suas vivências. Dificilmente a pessoa consegue voltar a ser o que era antes depois de uma agressão. Daí a necessidade de reconhecer o valor da integridade, que coloca o homem como sujeito de direitos e obrigações e os meios para prevenir, reparar e punir eventual violação desses direitos.

No contexto juslaboral brasileiro, a nomeada "reforma trabalhista", advinda da aprovação da Lei $n^{0}$ 13.467/2017, foi responsável pela alteração de diversos dispositivos da Consolidação das Leis Trabalhistas (CLT), com base em um paradigma global de reformas neoliberais, que, desde a década de 1970, tem engendrado a flexibilização e a precarização das relações de trabalho (DRUCK; DUTRA; SILVA, 2019; ANTUNES, 2014; 2018; 2020). Apesar de a reforma trabalhista se pautar na desconstrução da regulamentação protetiva das relações de trabalho, observa-se a regulamentação da reparação de danos de natureza extrapatrimonial no conjunto normativo juslaboral, cujas proposições, até então, estavam associadas ao Direito Civil. A inserção de título próprio na CLT para disciplinar o dano extrapatrimonial nas relações de trabalho, estabelecendo os parâmetros para a sua aplicação, bem como para a fixação da reparação pecuniária, foi uma novidade inserida no artigo 223-A e seguintes da CLT. No Quadro 2 é possível observar o que a Lei no 13.467/2017 definiu como dano extrapatrimonial nas relações de trabalho. 


\section{QUADRO 2 - DANO EXTRAPATRIMONIAL NA LEI Nº 13.467/2017}

\section{Lei $n^{0} 13.467 / 2017$}

Denominação: dano extrapatrimonial.

Hipóteses de incidência do assédio moral: causa dano de natureza extrapatrimonial a ação ou omissão que ofenda a esfera moral ou existencial da pessoa física ou jurídica. (Art. 223-B).

Dano à pessoa jurídica: reconhecimento de que a pessoa jurídica também pode ser afetada pelo dano extrapatrimonial. (Art. 223-B)

Delimitação dos danos à pessoa física: a honra, a imagem, a intimidade, a liberdade de ação, a autoestima, a sexualidade, a saúde, o lazer e a integridade física são os bens juridicamente tutelados inerentes à pessoa física. (Art. 223-C).

Delimitação dos danos à pessoa jurídica: a imagem, a marca, o nome, o segredo empresarial e o sigilo da correspondência são bens juridicamente tutelados inerentes à pessoa jurídica. (Art. 223-D)

Parametrização do dano extrapatrimonial: (Art. $223-\mathrm{G}, \S 1^{\circ} \mathrm{e} \S 2^{\circ}$ )

I. ofensa de natureza leve, até três vezes o último salário contratual do ofendido;

II. ofensa de natureza média, até cinco vezes o último salário contratual do ofendido;

III. ofensa de natureza grave, até vinte vezes o último salário contratual do ofendido;

IV. ofensa de natureza gravíssima, até cinquenta vezes o último salário contratual do ofendido.

Se o ofendido for pessoa jurídica, a indenização será fixada com observância dos mesmos parâmetros estabelecidos, mas em relação ao salário contratual do ofensor.

Tarifação em caso de reincidência: na reincidência entre partes idênticas, o juízo poderá elevar ao dobro o valor da indenização. (Art. 223-G, $\S 3^{\circ}$ )

Elementos a serem considerados pelo juiz: (Art. 223-G).

I - a natureza do bem jurídico tutelado;

II - a intensidade do sofrimento ou da humilhação;

III - a possibilidade de superação física ou psicológica;

IV - os reflexos pessoais e sociais da ação ou da omissão;

V - a extensão e a duração dos efeitos da ofensa;

VI - as condições em que ocorreu a ofensa ou o prejuízo moral;

VII - o grau de dolo ou culpa;

VIII - a ocorrência de retratação espontânea;

IX - o esforço efetivo para minimizar a ofensa;

X - o perdão, tácito ou expresso;

XI - a situação social e econômica das partes envolvidas;

XII - o grau de publicidade da ofensa.

Responsabilidade solidária ou subsidiária: são responsáveis pelo dano extrapatrimonial todos os que tenham colaborado para a ofensa ao bem jurídico tutelado, na proporção da ação ou da omissão. (Art. 223-E).

Cumulação de danos patrimoniais: a reparação por danos extrapatrimoniais pode ser pedida cumulativamente com a indenização por danos materiais decorrentes do mesmo ato lesivo. (Art. 223-F)

Fonte: Elaborado pelos autores de acordo com a Lei no 13.467/2017 (BRASIL, 2017a).

Relevante mencionar que, diante da celeuma advinda da tarifação do dano extrapatrimonial com base na verba salarial auferida pela vítima, sua base de cálculo foi alterada para o valor do limite máximo dos benefícios do Regime Geral de Previdência Social (RGPS), por meio da Medida Provisória $n^{\circ} 808 / 2017$; tendo em vista que o cálculo da indenização por dano moral e ofensa à honra com base no salário do trabalhador feria o princípio de isonomia. Logo, o indivíduo que tivesse um salário menor teria direito a uma indenização menor quando comparado a outro que sofresse o mesmo tipo de ofensa, embora com maior remuneração. No Quadro 3 faz-se referência às alterações: 


\section{QUADRO 3 - COMPARATIVO ENTRE LEI No 13.467/2017 E MEDIDA PROVISÓRIA No 808/2017}

\begin{tabular}{|c|c|}
\hline Lei ${ }^{0} \mathbf{1 3 . 4 6 7 / 2 0 1 7}$ & Medida Provisória nº 808/2017 \\
\hline $\begin{array}{l}\text { Parametrização do dano extrapatrimonial: } \\
\text { I. ofensa de natureza leve, até três vezes o último } \\
\text { salário contratual do ofendido; } \\
\text { II. ofensa de natureza média, até cinco vezes o último } \\
\text { salário contratual do ofendido; } \\
\text { III. ofensa de natureza grave, até vinte vezes o último } \\
\text { salário contratual do ofendido; } \\
\text { IV. ofensa de natureza gravíssima, até cinquenta vezes } \\
\text { o último salário contratual do ofendido. }\end{array}$ & $\begin{array}{l}\text { Parametrização do dano extrapatrimonial: } \\
\text { I - para ofensa de natureza leve - até três vezes o } \\
\text { valor do limite máximo dos benefícios do RGPS; } \\
\text { II - para ofensa de natureza média - até cinco vezes o } \\
\text { valor do limite máximo dos benefícios do RGPS; } \\
\text { III - para ofensa de natureza grave - até vinte vezes o } \\
\text { valor do limite máximo dos benefícios do RGPS; } \\
\text { IV - para ofensa de natureza gravíssima - até cin- } \\
\text { quenta vezes o valor do limite máximo dos benefícios } \\
\text { do RGPS. }\end{array}$ \\
\hline $\begin{array}{l}\text { Tarifação em caso de reincidência: na reincidência } \\
\text { entre partes idênticas, o juízo poderá elevar ao dobro o } \\
\text { valor da indenização. }\end{array}$ & $\begin{array}{l}\text { Tarifação em caso de reincidência: manteve a tari- } \\
\text { fação, mas estabeleceu que a reincidência ocorrerá se } \\
\text { ofensa idêntica ocorrer no prazo de até dois anos, con- } \\
\text { tado do trânsito em julgado da decisão condenatória. }\end{array}$ \\
\hline $\begin{array}{l}\text { Caso de danos extrapatrimoniais decorrentes } \\
\text { morte: não há diferenciação. }\end{array}$ & $\begin{array}{l}\text { Caso de danos extrapatrimoniais decorrentes de } \\
\text { morte: estabeleceu que os parâmetros estabelecidos } \\
\text { não se aplicam. }\end{array}$ \\
\hline
\end{tabular}

Fonte: Elaborado pelos autores de acordo com a Lei no 13.467/2017 e Medida Provisória nº 808/2017 (BRASIL, 2017a, 2017b)

A Constituição da República Federativa do Brasil de 1988, no artigo 62, §7º , estabelece que toda medida provisória deve ser objeto de aprovação pelo Congresso Nacional, sob pena de perder sua validade. Decorrido o prazo previsto legalmente, a Medida Provisória $n^{0}$ 808/2017 não foi submetida ao Congresso para aprovação e perdeu sua validade a partir de 23 de abril de 2018. Tal fato implicou na manutenção da redação original da reforma trabalhista, ressalvados apenas os atos acobertados pelo curto período em que a medida provisória permaneceu em vigor. Dessa maneira, as disposições afetas à parametrização do dano extrapatrimonial previstas na Lei $\mathrm{n}^{\mathrm{o}} 13.467 / 2017$, embora contestáveis do ponto de vista das normas protetivas do trabalho, encontram-se em vigor.

Reis (2018) afirma que o legislador fere a dignidade do trabalhador, assim como os princípios constitucionais, ao tarifar o dano extrapatrimonial com base em critérios que precificam a importância humana com base no valor da verba salarial auferida. Assim, diante dos preceitos normativos insertos na CLT, criam-se duas categorias de obreiros: o trabalhador que vale mais - por auferir melhor remuneração -, e o trabalhador cuja vida e integridade física e moral valem menos - porquanto detentor de uma verba remuneratória inferior -, independentemente de a ofensa recebida ser a mesma.

\section{ASSÉDIO EM INSTITUIÇÕES FINANCEIRAS}

Maciel et al. (2007) apontam que as mudanças decorrentes da reestruturação produtiva trouxeram grandes transformações no trabalho, especialmente no contexto do trabalho bancário. Resende e Mendes (2004) salientam que as instituições bancárias passaram por mudanças que se deram, principalmente, por meio de privatizações e fusões e que trouxeram como consequência redução no quadro de funcionários, exigências cada vez maiores de produtividade e maior contratação de empregados terceirizados. Essa reestruturação produtiva trouxe como 
consequência a precarização do trabalho (ANTUNES, 2018), que é definida por Franco, Druck e Seligmann-Silva como

um processo multidimensional que altera a vida dentro e fora do trabalho. Nas empresas se expressa em formas de organização pautadas no just-in-time, na gestão pelo medo, nas práticas participativas forçadas, na imposição sutil de autoaceleração, na multifuncionalidade, dentre outros métodos voltados ao controle maximizado. São processos de dominação que mesclam insegurança, incerteza, sujeição, competição, proliferação da desconfiança e do individualismo, sequestro do tempo e da subjetividade. [...]. A desvalorização simbólica, com a corrosão do sistema de valores, da autoimagem e das representações da inserção de cada um na estrutura social. (2010, p. 231).

A cartilha nomeada Assédio moral em estabelecimentos bancários, lançada pelo Ministério Público do Trabalho (2013), aponta as características do ambiente bancário que o tornam mais propício à prática do assédio moral. Dentre elas se destacam: (i) estrutura fortemente hierarquizada; (ii) burocracia excessiva; (iii) forte pressão por produtividade e venda de produtos bancários; (iv) metas que desconsideram a situação econômica conjuntural; (v) baixa importância dada pela empresa à relação entre o profissional e o cliente; (vi) discrepância entre a jornada de trabalho real e a jornada de trabalho formal, registrada em cartões de ponto; (vii) políticas de demissão e de transferências para agências mais distantes dentro da mesma localidade; (viii) tratamento hostil dispensado pelos gestores dos estabelecimentos bancários e pelos demais colegas aos empregados convalescentes; (ix) exigência de um perfil, que pode ser estético ou baseado em uma análise da vida pregressa do empregado; (x) resistência ao engajamento sindical, com criação de entraves; (xi) insegurança nas agências bancárias, com casuística de agressões físicas e psicológicas decorrentes de constantes assaltos; (xii) processo de qualificação permanente; (xiii) progressão na carreira vinculada ao cumprimento de metas; (xiv) políticas institucionais de competição entre os bancários; (xv) institucionalização de um padrão de comportamento dos bancários pautado nas seguintes premissas: ser amável, comunicativo, ter disposição para vender produtos e fidelizar clientes.

Soares e Villela fortalecem essa argumentação ao afirmarem que

no cenário de uma instituição financeira cercado de competitividade, focado em lucros e resultados, com os valores humanos postos em segundo plano, o assédio moral passa a ser utilizado como uma ferramenta para disciplinar as pessoas da organização ou como um modo deliberado de exercer o poder com o propósito de atingir os objetivos do banco. (2012, p. 210).

Para Soboll, “essa política organizacional apresenta-se permissiva, promotora e conivente com a violência como estratégia de gestão" (2008, p. 106). Urabe e Padilha (2016) complementam que os fatores que tornam o ambiente bancário favorável para o assédio moral trazem como resultado um alto risco de adoecimento ao trabalhador. Finazzi destaca que "no Brasil, nas últimas décadas, a taxa de suicídio de bancários vem crescendo, bem como a pressão por resultados e a imposição de metas inalcançáveis" (2009, p. 29).

Segundo dados do Instituto Nacional do Seguro Social (INSS), obtidos na pesquisa realizada pelo Sindicato dos Bancários de São Paulo, Osasco e Região (WROLLI, 2019), o número de trabalhadores bancários afastados por doenças relacionadas à atividade laboral cresceu $30 \%$ entre os anos de 2009 e 2017 . Os dados apresentados demonstram que metade dos casos relatados foram decorrentes de transtornos comportamentais e mentais, cujo crescimento foi de $61,5 \%$ no período analisado. A sobrecarga de trabalho, a pressão para o cumprimento de 
metas abusivas, a intensificação do ritmo de trabalho e o assédio moral são os principais fatores que levam os trabalhadores do sistema financeiro brasileiro ao adoecimento.

Conforme Soares e Villela (2012), o aumento do número de trabalhadores afastados por problemas psíquicos promoveu maior visibilidade para as práticas de assédio moral e suas consequências; sobretudo se considerado o aumento de gastos públicos no sistema de saúde e com os pedidos de aposentadoria por invalidez.

\section{METODOLOGIA}

A presente pesquisa é classificada como descritiva quanto ao seu objetivo (GIL, 2008). Houve utilização de método qualitativo e quantitativo, bem como dos seguintes procedimentos técnicos de pesquisa: bibliográfico, documental e de levantamento, com a realização de entrevista semiestruturada, com amostra não probabilística por conveniência.

Para cumprir o objetivo proposto na pesquisa e estudar a jurisprudência do Tribunal Regional do Trabalho da $3^{\text {a }}$ Região (TRT-MG), correspondente ao período compreendido entre janeiro e junho de 2018, sobre os casos de assédio moral sofridos por empregados do setor bancário de Minas Gerais, fez-se necessário, primeiramente, delimitar o conceito teórico do assédio moral e abordar as mudanças legislativas na reparação extrapatrimonial do dano sofrido no ambiente de trabalho. Nesse sentido, foi feito um levantamento das bibliografias publicadas sobre o tema.

O estudo da jurisprudência do TRT-MG acerca da prática de assédio moral nas organizações pressupõe o direcionamento do olhar para o contexto fático (LIBÓRIO et al., 2016). Porquanto, parte-se da análise da realidade prática vivenciada pelos bancários na constância da relação juslaboral. Por meio da jurisprudência do TRT-MG, foi possível identificar as práticas mais comuns de assédio moral sofridas por empregados das instituições financeiras de Minas Gerais. De igual modo, a análise das decisões permitiu a identificação dos elementos narrativos com os quais os julgadores construíram seus argumentos, assim como a avaliação crítica dos fundamentos que subsidiaram a improcedência ou não do pedido de reparação do dano por assédio moral.

Para o levantamento de dados, foi realizado o acesso ao site do TRT-MG, no menu "Jurisprudência" e, posteriormente, em "Acórdão na íntegra", sendo selecionada a opção "Pesquisa Textual". Em seguida, no campo "Com todas as palavras", foram pesquisadas as palavras-chave "assédio moral banco", com publicação/disponibilização no período de interesse (01/01/2018 a 30/06/2018). A pesquisa resultou inicialmente em 292 acórdãos e, então, foi refinada, a fim de se estudar apenas o grupo de interesse, finalizando em 147 casos analisados. Os resultados obtidos, bem como sua análise, são evidenciados na próxima seção.

Desse modo, o estudo aborda apenas as práticas de assédio moral que sofreram judicialização, por meio do ajuizamento de reclamatória trabalhista tendente à reparação dos danos extrapatrimoniais. Casos de assédio moral não são relatados frequentemente porque as vítimas sentem medo de sofrer represálias e, não raro, esses casos são relatados de forma sigilosa.

Para o levantamento, a seleção do participante foi realizada por conveniência. Utilizouse uma entrevista individual semiestruturada com o representante do Sindicato dos Bancários de Belo Horizonte e Região, em que os principais temas abordados foram: o assédio moral no ambiente bancário, as práticas mais usuais do fenômeno, a forma e o processamento das denúncias administrativas junto ao órgão sindical e o perfil dos trabalhadores bancários que 
sofreram assédio. Embora se reconheça a limitação imposta pela realização da entrevista, intencionou-se correlacionar, de forma ilustrativa, os resultados da pesquisa jurisprudencial com os dados trazidos pelo entrevistado, com base em suas experiências práticas com o problema pesquisado, enquanto atuante representante sindical bancário. As manifestações do informantechave, entretanto, devem ser examinadas com cautela, já que ele se encontra vinculado a uma instituição que tem por finalidade justamente a defesa dos trabalhadores bancários.

\section{ANÁLISE E DISCUSSÃO DOS RESULTADOS}

Foram pesquisados os acórdãos proferidos pelo Tribunal Regional do Trabalho da $3^{\mathrm{a}}$ Região no período compreendido entre 01/01/2018 e 30/06/2018, totalizando 147 acórdãos, sendo que todos eles foram proferidos após a aprovação e sanção da Lei $\mathrm{n}^{0} 13.467$, de 13 de julho de 2017. Dentre os acórdãos, 78 foram proferidos durante a vigência da Medida Provisória $\mathrm{n}^{\mathrm{o}}$ 808/2017 e o restante - equivalente a 69 -, após 23 de abril de 2019, data em que a Medida Provisória caducou.

A análise das reclamatórias trabalhistas restringiu-se aos acórdãos publicados no período temporal de análise, incluindo-se as sentenças monocráticas respectivas. Não houve, contudo, a análise de eventuais recursos processuais e acórdãos proferidos pelo Tribunal Superior do Trabalho (TST) e demais Tribunais Superiores nas ações incluídas na pesquisa.

Observou-se que, no período analisado, não houve jurisprudências com base na Lei ${ }^{\circ}$ 13.467/2017 e na Medida Provisória $n^{\circ}$ 808/2017. Em relação aos contratos encerrados antes da vigência da Lei $n^{0} 13.467 / 2017$, o artigo $6^{\circ}$ da Lei de Introdução às Normas do Direito Brasileiro (Decreto-Lei $n^{\circ} 4.657 / 1942$ ) disciplina questões relativas ao ato jurídico perfeito e à coisa julgada, vedando que lei posterior prejudique o direito adquirido, o que se aplica àqueles contratos encerrados em data anterior a 11 de novembro de 2017.

A análise dos julgados permite inferir um atraso do Poder Judiciário para assimilar as mudanças legislativas. Reis (2018) destaca que, devido à conflitualidade e complexidade das alterações promovidas pela reforma trabalhista, observa-se a ausência de unanimidade quanto aos posicionamentos e interpretações adotados pelos juízes do trabalho. Enquanto alguns juízes passaram a aplicar imediatamente os novos dispositivos da CLT, a maioria optou por aguardar e analisar seus respectivos impactos nas relações de trabalho. A autora ressalta ainda que foram ajuizadas quase duas dezenas de ações que questionam a constitucionalidade de artigos da Lei $n^{\circ} 13.467 / 2017$, sendo que a maior parte delas ainda aguarda análise da corte constitucional.

O Gráfico 1 apresenta a quantidade de acórdãos proferidos por mês no período analisado, bem como sua porcentagem correspondente aos 147 analisados no total. A publicação dos acórdãos ocorreu com maior incidência no mês de maio, e os processos eram oriundos de 46 cidades de Minas Gerais, sendo as mais recorrentes: Belo Horizonte (21,09\%), Juiz de Fora, (10,20\%), Uberlândia (6,12\%), representando juntas 37,41\% do total de cidades. 


\section{GRÁFICO 1 - NÚMERO DE PROCESSOS POR MÊS}

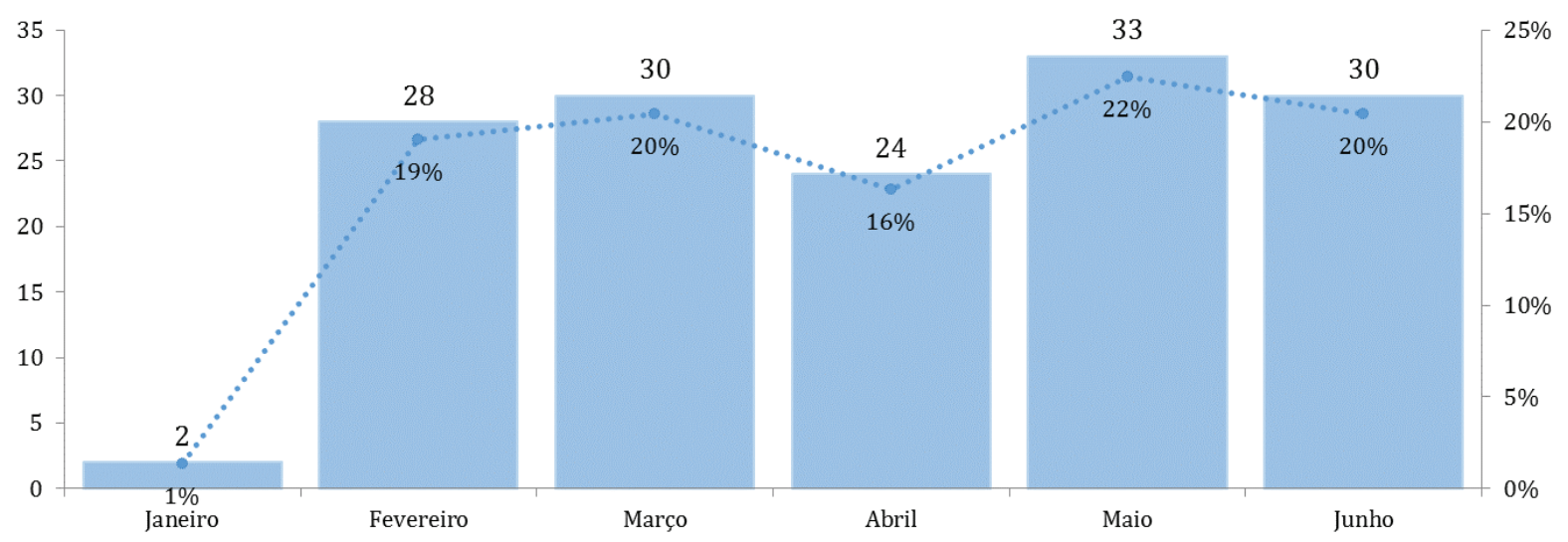

Fonte: Dados da pesquisa (2018).

Dentre os réus nos processos, $81 \%$ eram bancos privados, $16 \%$ bancos mistos e $3 \%$ bancos públicos 5 . O Banco Bradesco S.A. e o Banco Itaú S.A. responderam, igualmente, a 38 ações judiciais, sendo réus, conjuntamente, em 51,7\% dos processos no período pesquisado. O Banco do Brasil, empresa de economia mista integrante da administração pública indireta, aparece na $3^{\mathrm{a}}$ posição no Quadro 4, que identifica e apresenta a frequência com que as instituições bancárias aparecem como réus nos processos analisados.

\section{QUADRO 4 - IDENTIFICAÇÃO DAS INSTITUIÇÕES BANCÁRIAS}

\begin{tabular}{lll}
\hline \multicolumn{1}{c}{ Nome do banco } & Quantidade de Processos & Frequência (\%) \\
\hline Banco Bradesco S.A. & 38 & $\mathbf{2 5 , 8 5 \%}$ \\
\hline Itaú Unibanco S.A. & 38 & $\mathbf{2 5 , 8 5 \%}$ \\
\hline Banco do Brasil S.A. & 23 & $\mathbf{1 5 , 6 5 \%}$ \\
\hline Banco Santander S.A. & 15 & $\mathbf{1 0 , 2 0 \%}$ \\
\hline Banco Mercantil do Brasil S.A. & 13 & $\mathbf{8 , 8 4 \%}$ \\
\hline Caixa Econômica Federal & 5 & $\mathbf{3 , 4 0 \%}$ \\
\hline Kirton Bank S.A. Banco Múltiplo & 3 & $\mathbf{2 , 0 4 \%}$ \\
\hline HSBC Bank Brasil S.A. Banco Múltiplo & 2 & $\mathbf{1 , 3 6 \%}$ \\
\hline Banco BMG S.A. & 2 & $\mathbf{1 , 3 6 \%}$ \\
\hline Banco Safra S.A. & 3 & $\mathbf{2 , 0 4 \%}$ \\
\hline BV Financeira S.A. & 1 & $\mathbf{0 , 6 8 \%}$ \\
\hline Bancoob & 1 & $\mathbf{0 , 6 8 \%}$ \\
\hline Banco Semear S.A. & 1 & $\mathbf{0 , 6 8 \%}$ \\
\hline
\end{tabular}

5 A Lei $\mathrm{n}^{\mathrm{o}}$ 200, de 25 de fevereiro de 1967, modificada pelo Decreto-lei $\mathrm{n}^{\circ}$ 900, de 29 de setembro de 1969, e pelo Decreto-lei $\mathrm{n}^{\circ} 2.299$, de 21 de novembro, em seus incisos II e III, do artigo $5^{\circ}$, dispõe que empresa pública é a entidade dotada de personalidade jurídica de direito privado, com patrimônio próprio e capital exclusivo da União, criado por lei para a exploração de atividade econômica que o governo seja levado a exercer por força de contingência ou de conveniência administrativa, podendo revestir-se de qualquer das formas admitidas em direito. Dispõe ainda que a sociedade de economia mista é a entidade dotada de personalidade jurídica de direito privado, criada por lei para a exploração de atividade econômica, sob a forma de sociedade anônima, cujas ações com direito a voto pertençam na maioria à União ou a à entidade da Administração Indireta. 


\begin{tabular}{lll}
\hline Banco Cetelem S.A. & 1 & $0,68 \%$ \\
\hline Banco Citibank S.A. & 1 & $0,68 \%$ \\
\hline
\end{tabular}

Fonte: Dados da pesquisa (2018).

Moccia (2017) salienta que empresas públicas e sociedades de economia mista são instrumentos de ação do Estado, auxiliares do Poder Público, que devem buscar interesses superiores aos tão somente privados. Contudo, o representante do Sindicato de Belo Horizonte e Região aponta que

O Banco do Brasil, por ser uma economia mista, é um banco que a gente entendia que poderia ser um banco que cobrasse até menos, mas hoje no Banco do Brasil a meta é abusiva tanto quanto no Santander, Bradesco, Itaú e Mercantil. Você está vendo a mudança de postura que está havendo das direções desse banco de cobrança de metas e aí você vê o resultado desses lucros astronômicos, em decorrência desta pressão. $(\text { Entrevistado })^{6}$

Ao analisar o gênero dos autores das reclamatórias trabalhistas, foi observado que $52 \%$ são do gênero feminino e $48 \%$ do gênero masculino. Esse resultado está em consonância com outros estudos. Einarsen et al. (2011) afirmam que as mulheres tendem a ser vítimas de assédio moral com maior frequência, o que indica que determinados grupos de pessoas podem apresentar um risco adicional de ocorrência de assédio.

No que tange ao gênero dos assediadores, foi constatado que $32 \%$ eram do gênero masculino e $12 \%$ do gênero feminino. Por outro lado, $14 \%$ dos processos correspondem à ocorrência de assédio organizacional e em $42 \%$ das ações judiciais não foi identificado o autor do assédio.

Beswick, GORE e Palferman (2006) definem que o assédio organizacional se relaciona diretamente às questões do contexto, processo e gestão do trabalho. Estima-se que a parcela dos casos em que não foi feita referência aos autores do assédio esteja associada ao assédio organizacional, apesar de o termo não ter sido empregado nos julgados. A título exemplificativo, infere-se a caracterização do assédio organizacional em um dos julgados analisados na pesquisa:

\begin{abstract}
No caso dos autos, entendo que o banco reclamado praticou assédio moral institucional, que ocorre quando o agressor, que no caso, é a própria pessoa jurídica, por meio de seus administradores, utiliza-se de uma política de gestão desumana para aumentar os seus lucros criando uma verdadeira cultura institucional e de humilhação, o que evidencia a pouca importância conferida pelas instituições bancárias ao fator humano em detrimento do econômico. (TRT-3, 2018e, p. 2).
\end{abstract}

Ao desconsiderar a parcela de processos em que não foi identificado o autor do assédio moral e em que foi categorizado assédio organizacional, observa-se que há prevalência de assediadores do gênero masculino (73\%), sendo apenas $27 \%$ dos assediadores do gênero feminino. Essa discrepância não é observada ao analisar o gênero dos autores dos processos.

Leone e Teixeira (2016) explicam que embora mulheres tenham alcançado maior participação em profissões de alto prestígio, a segregação permanece, e elas têm enfrentado barreiras não visíveis no mercado de trabalho, como a maior dificuldade de ascensão a cargos de chefia. Consequentemente, verifica-se uma maior concentração de trabalhadoras em

\footnotetext{
6 Pesquisa de campo realizada com o representante do Sindicato de Belo Horizonte e Região em 02 nov. 2018.
} 
especialidades com menor remuneração e menor prestígio. O que, a princípio, poderia explicar também um maior número de mulheres a sofrerem assédio moral.

A pesquisa apontou a preponderância do assédio moral vertical descendente $(44,3 \%)$, praticado pelo superior hierárquico em relação ao seu subordinado. A pesquisa apontou também que em 14,3\% dos casos ocorreu assédio organizacional; $0,7 \%$ assédio horizontal e em 40,8\% não houve identificação.

Freitas (1991) destaca que a hierarquia é um traço forte na cultura organizacional brasileira, que transparece pela centralização do poder, passividade de grupos inferiores hierarquicamente e distanciamento nas relações de indivíduos de cargos de níveis diferentes. A autora aponta ainda que um dos fatores dominantes para a ocorrência do assédio é o desequilíbrio de poder e a incapacidade de a vítima se defender das agressões.

A respeito do objeto de discussão das causas ajuizadas (Quadro 5), as quatro causas de maior recorrência são: pressões e cobranças abusivas pelo cumprimento de metas $(40 \%)$, situações vexatórias e humilhantes (19,3\%), ameaças de demissão (8,42\%) e imposição abusiva de metas (7,37\%), representando juntas $75,09 \%$ do total de condutas abusivas.

\section{QUADRO 5 - Identificação das causas ajuizadas}

\begin{tabular}{|c|c|c|}
\hline Motivo & Quantidade & Frequência \\
\hline Pressões e cobranças abusivas pelo cumprimento de metas & 114 & $40,00 \%$ \\
\hline Situações vexatórias e humilhantes & 55 & $19,30 \%$ \\
\hline Ameaças de demissão & 24 & $8,42 \%$ \\
\hline Imposição abusiva de metas & 21 & $7,37 \%$ \\
\hline Violência verbal & 20 & $7,02 \%$ \\
\hline Atos discriminatórios (idade, gênero, cor) & 9 & $3,16 \%$ \\
\hline Ameaça e/ou transferência de agência & 7 & $2,46 \%$ \\
\hline Impedimento do uso do banheiro & 6 & $2,11 \%$ \\
\hline Mudanças de ambiente de trabalho e especificidades das suas funções & 5 & $1,75 \%$ \\
\hline Exclusão/isolamento proposital & 3 & $1,05 \%$ \\
\hline Submissão do trabalhador ao ócio de forma continuada & 3 & $1,05 \%$ \\
\hline Atribuir propositalmente tarefas inferiores às suas competências & 3 & $1,05 \%$ \\
\hline Imposição de obstáculos para o cumprimento de metas & 2 & $0,70 \%$ \\
\hline Ameaça de rebaixamento funcional & 2 & $0,70 \%$ \\
\hline Exigência de constante disponibilidade em prejuízo do descanso pessoal & 2 & $0,70 \%$ \\
\hline Imposição de jornada excessiva & 2 & $0,70 \%$ \\
\hline Divulgação de informações íntimas para causar constrangimento & 2 & $0,70 \%$ \\
\hline $\begin{array}{l}\text { Exigência de realização de operações financeiras não autorizadas pela Legis- } \\
\text { lação }\end{array}$ & 2 & $0,70 \%$ \\
\hline Sobrecarga de trabalho & 1 & $0,35 \%$ \\
\hline Ameaça de descomissionamento & 1 & $0,35 \%$ \\
\hline Impedimento de ir ao médico & 1 & $0,35 \%$ \\
\hline
\end{tabular}

Fonte: Dados da pesquisa (2018).

Sobre a ação abusiva mais recorrente, o representante sindical entrevistado afirma que "o Sindicato entende que tem que ter metas sim; mas, estas metas não podem ser abusivas. 
Então, o tempo todo a gente está denunciando a questão de metas abusivas" (Entrevistado) 7 . A respeito de situações vexatórias e humilhantes, o depoimento do entrevistado é ilustrativo:

Já vi muitos casos também de diminuir o trabalho do outro, chamando-o de incompetente, tem muito isso, o menosprezo pela capacidade do outro trabalhar, reduzir a pessoa ao seu resultado. Você não fez a meta, então você é um puto [sic]. Nós tivemos um caso de um banco que uma gerente trancou uma funcionária e falou: você só sai daí se cumprir todas as metas. Foi um despropósito, isso é um cárcere privado. (Entrevistado) ${ }^{8}$.

Dentre as causas ajuizadas, de acordo com os subgrupos de ações abusivas classificadas por Hirigoyen (2002), 76,19\% das ações abusivas estão classificadas em deterioração proposital das condições de trabalho, 14,29\% em atentado contra a dignidade, 4,76\% em isolamento e recusa de comunicação e $4,76 \%$ em violência verbal.

No que se refere ao parecer do juiz a respeito dos processos, $63,27 \%$ das reclamatórias trabalhistas foram julgadas improcedentes, o que sugere que as alegações não estão sendo bem fundamentadas e/ou provadas. De outro lado, é possível assumir que as causas relativas ao ajuizamento podem não se enquadrar objetivamente na definição legal de assédio moral, supostamente por estarem associadas a agressões pontuais associadas ao estresse, ao mau humor ou à ausência de urbanidade no ambiente laboral, conforme alude Silva (2011).

No que concerne aos tipos de provas apresentadas para a fundamentação das denúncias, destaca-se que em $75 \%$ foram utilizadas testemunhas, a fim de corroborar as denúncias de assédio moral; em $9 \%$ dos casos foi apresentado laudo pericial; em $9 \%$ não foram apresentadas provas; em $6 \%$ foi apresentada prova documental e em apenas 1\% houve inspeção judicial.

Dentre as razões da não procedência dos pedidos indenizatórios, destaca-se que a não comprovação pelos depoimentos das testemunhas é o motivo mais frequente (64\%). Sobre o assunto, o representante sindical entrevistado afirma:

a gente sabe do dificultador [sic] que é pegar uma testemunha se ela está trabalhando no banco ainda. Eu não sei os casos que você está pesquisando, mas você vai ver que $100 \%$ dos bancários provavelmente já se desligaram do banco. (Entrevistado) ${ }^{9}$.

A dificuldade de comprovação das condutas abusivas perante a Justiça do Trabalho, por meio da constituição de prova testemunhal, é ressaltada por Battistelli, Amazarray e Koller (2011), dado o receio que os colegas do trabalhador vitimado têm de sofrer represálias ou mesmo de perderem o posto de trabalho.

No Quadro 6 verifica-se a taxa de procedência do pedido indenizatório por quantidade de processos. Observa-se que a inspeção judicial, que é fundada na percepção direta do juiz, teve maior taxa de procedência. Contudo, sua adoção pelo magistrado é pouco frequente, tendo sido feita apenas uma vez nos 147 processos analisados.

\footnotetext{
7 Pesquisa de campo realizada com o representante do Sindicato de Belo Horizonte e Região em 02 nov. 2018.

Pesquisa de campo realizada com o representante do Sindicato de Belo Horizonte e Região em 02 nov. 2018.

Pesquisa de campo realizada com o representante do Sindicato de Belo Horizonte e Região em 02 nov. 2018.
} 


\section{QUADRO 6 - TAXA DE PROCEDÊNCIA PEDIDO INDENIZATÓRIO}

\begin{tabular}{lcc}
\hline Tipo de prova & $\begin{array}{c}\text { Quantidade de } \\
\text { processos }\end{array}$ & $\begin{array}{c}\text { Taxa de procedência do pedido } \\
\text { indenizatório (\%) }\end{array}$ \\
\hline Inspeção judicial & 1 & $100,0 \%$ \\
Laudo pericial & 16 & $56,3 \%$ \\
Testemunhas & 125 & $41,6 \%$ \\
Prova documental & 10 & $30,0 \%$ \\
Não foi apresentado & 15 & $0,0 \%$ \\
\hline
\end{tabular}

Fonte: Dados da pesquisa (2018).

A apresentação de laudo pericial foi a segunda prova com maior efetividade na procedência de pedidos indenizatórios. Em um dos processos analisados, contudo, o voto condutor da Desembargadora Relatora mostrou-se em discordância com o laudo pericial apresentado e julgou como procedente a reclamatória trabalhista:

Designada perícia médica (Id 9c37086), o perito esclareceu que a autora fora diagnostica com as doenças de CID F32.2, F41.0 e F41.1 (episódio depressivo grave sem sintomas psicóticos, transtorno de pânico e transtorno de ansiedade), acrescentando que o CNAE da ré - 6421 - não se enquadra no intervalo de CID F30 e F40. Em função disso, concluiu que "Não há nexo causal entre a patologia diagnosticada pelo psiquiatra e a função exercida pela Reclamante". Todavia, se por um lado a questão é eminentemente técnica, não se pode olvidar que a medicina não é uma ciência exata, com diagnósticos sempre precisos. Assim, estou convencida de que a execução do trabalho contribuiu para a eclosão ou o agravamento das doenças adquiridas pela autora, haja vista as condições de trabalho a que foi submetida. Assim, in casu, não se pretende simplesmente invalidar o laudo técnico oficial, mas tão somente dele extrair outros elementos para motivar o convencimento do Juízo, conforme autoriza o princípio da persuasão racional, segundo o qual é livre o Julgador para apreciar as provas na formação de seu convencimento, devendo, todavia, fundamentar sua decisão (art. 93, IX, da CF e art. 371 do CPC). (TRT-3, 2018e, p. 2).

$\mathrm{O}$ acórdão acima destaca o entendimento dos julgadores quanto à possibilidade de a doença ter outra origem que não a ocupacional, tal como uma predisposição individual, insuficiente para afastar o nexo epidemiológico com o trabalho, o qual, para efeito de reconhecimento de doença ocupacional, não precisa ter causa exclusiva, sendo suficiente que a atividade realizada possa ter causado ou até mesmo contribuído para o surgimento da doença ou seu agravamento.

A pressão e a cobrança abusiva de metas, causas mais recorrentes de ajuizamento de reclamatória trabalhista, apresentaram percentual de 30,7\% de deferimento. No entanto, pressão e cobranças são frequentemente categorizadas como inerentes à atividade empresarial. A "gestão por estresse" (ou "gestão por pressão") objetiva a melhora da produtividade e a otimização do desempenho, sem haver intencionalidade maldosa (HIRIGOYEN, 2002; SOARES, VILLELA, 2012; SOBOLL, MIARA; MOSCALEWSKY, 2017). Essa posição, inclusive, é corroborada em um dos julgados:

A estratégia de organização e gerenciamento do trabalho regida por meio da estipulação e da cobrança de metas e de atribuição de prêmios gera naturalmente ambiente de competição, de desafios, e de estresse, o que não ofende, necessariamente, direitos de personalidade dos trabalhadores submetidos. (TRT-3, 2018e, p. 15) 
O Poder Judiciário, dessa forma, tem contribuído para a permanência de práticas abusivas ao legitimar a atuação dos empregadores quanto à cobrança excessiva, em vez de auxiliar em uma mudança de realidade social tendente a evitar as externalidades negativas advindas das práticas de assédio. Tal aspecto é esboçado em um dos acórdãos analisados:

A simples cobrança de metas de produção não passa do legítimo exercício do poder diretivo do empregador, para fazer frente às exigências de um mercado cada vez mais competitivo. Logo, aqueles que menos produzem naturalmente acabam sendo dispensados do emprego, sem que haja qualquer ilegalidade neste ato. Ademais, a imposição e cobrança de metas são situações rotineiras e características da atividade empresarial, sobretudo no setor bancário, que estão inseridas no poder diretivo do empregador. (TRT-3, 2018e, p. 4).

No que tange ao valor indenizatório, valores inferiores a $\mathrm{R} \$ 10.000,00$ representam $36,36 \%$ dos processos deferidos, conforme observado no Quadro 7.

\section{QUADRO 7 - Valor indenizatório}

\begin{tabular}{lcc}
\hline \multicolumn{1}{c}{ Faixa de valor } & Quantidade & Frequência \\
\hline Valor $<\mathrm{R} \$ 10.000$ & 20 & $36,36 \%$ \\
$\mathrm{R} \$ 10.000 \leq$ Valor $<\mathrm{R} \$ 20.000$ & 13 & $23,64 \%$ \\
$\mathrm{R} \$ 20.000 \leq$ Valor $<\mathrm{R} \$ 30.000$ & 9 & $16,36 \%$ \\
$\mathrm{R} \$ 30.000 \leq$ Valor $<\mathrm{R} \$ 40.000$ & 6 & $10,91 \%$ \\
$\mathrm{R} \$ 40.000 \leq$ Valor $<\mathrm{R} \$ 50.000$ & 3 & $5,45 \%$ \\
Valor $\geq \mathrm{R} \$ 50.000$ & 4 & $7,27 \%$ \\
\hline Total & 55 & $100,00 \%$ \\
\hline
\end{tabular}

Fonte: Dados da pesquisa (2018).

No processo $\mathrm{n}^{\mathrm{o}}$ 0012006-89.2015.5.03.0168, julgado pelo TRT-MG, evidencia-se a complexidade e subjetividade do arbitramento da quantia indenizatória, tendo em vista que a monetização de toda e qualquer ação humana pode fazer com que a saúde e a higidez física do trabalhador tornem-se simples itens de consumo dentro da engrenagem comercial; isto é, os empresários não devem estar em posição de ponderar, à sua conveniência, entre a adoção de uma gestão de cobrança abusiva e excessiva de metas - que causem danos aos trabalhadores e gerem maior lucratividade, ainda que eventualmente sejam pagas indenizações - ou a alteração de suas práticas de gestão. Nesse sentido, o caráter pedagógico-punitivo da indenização deve ser pensado de forma a servir de desestímulo para o empregador.

Ora, é sabido que os empregados do setor bancário sofrem constante e diária pressão por parte dos seus superiores hierárquicos, os quais, por sua vez, são pressionados a também "baterem metas". É notória a política da suposta "meritocracia", também conhecida como a gestão empresarial importada dos Estados Unidos do "Work Hard, Play Hard", na qual aqueles que mais se esforçam, conseguem atingir a meta e terão salários melhores. Também é de conhecimento público que o lucro líquido dos bancos no Brasil chega à casa dos bilhões. Ademais, também é notória a repetição de casos que chegam à Justiça do Trabalho brasileira em que seus empregados denunciam ameaças constantes de perda do emprego em virtude de abuso do banco na estipulação e cobrança de metas. Tal fenômeno vem sendo denominado pela doutrina como gestão por stress ou straining. Desta forma, o caráter pedagógico da indenização [...] em que se tem um ofensor contumaz e que se utiliza do temor reverencial e incentiva os seus gestores a cobrar metas excessivas e de forma abusiva, deve ser pensado de forma a atribuir potencial de transformação da realidade social à decisão judicial. (TRT-3, 2018). 
A responsabilidade civil gera debates doutrinários e jurisprudenciais, posto que há divergentes entendimentos sobre sua função, podendo ser considerada unicamente reparatória ou pedagógica-punitiva, pensada de forma a servir de desestímulo para o empregador. Nesse aspecto, o tabelamento da reparação de danos de natureza extrapatrimonial trazido pela reforma trabalhista (Lei $\mathrm{n}^{\mathrm{o}} 13.467 / 2017$ ) prejudica o caráter pedagógico-punitivo da responsabilidade civil, na medida em que a limitação dos valores indenizatórios pode ser entendida como um mecanismo de análise custo-benefício para a manutenção de políticas organizacionais abusivas.

\section{CONSIDERAÇÕES FINAIS}

A flexibilização dos processos de trabalho, juntamente à precarização dos direitos trabalhistas, atualmente, dá-se por meio da criação ou alteração de leis com o objetivo de abolir direitos conquistados de cunho trabalhista previstos na Constituição da República Federativa do Brasil de 1988 e demais leis de cunho trabalhista e, dessa forma, compactua com os interesses das grandes corporações.

A pesquisa mostrou a preponderância do assédio moral vertical descendente $(44,3 \%)$, praticado pelo superior hierárquico em relação ao seu subordinado. Desse modo, o tabelamento da reparação de danos de natureza extrapatrimonial tende a afetar de forma mais intensa aqueles que são com maior frequência vítimas do assédio moral e formam a parte fragilizada nas relações de trabalho.

$\mathrm{O}$ assédio moral tem consequências danosas não somente para a higidez física e mental do trabalhador, mas também traz efeitos negativos para o governo e para a sociedade em geral, face aos elevados custos previdenciários e com a saúde. De igual modo, acarreta prejuízos financeiros para as organizações, em função do aumento de despesas decorrentes de absenteísmo, da elevada rotatividade, da queda na produtividade dos trabalhadores e dos gastos com processos judiciais.

$\mathrm{O}$ resultado da pesquisa mostrou que homens e mulheres, no período analisado, ajuizaram ações tendentes à reparação dos danos extrapatrimoniais advindos do assédio moral em similar proporção. Contudo, há uma grande disparidade ao se considerar o gênero dos assediadores. A pesquisa mostrou que, ao desconsiderar casos de assédio organizacional e casos em que não foi identificado o autor, $73 \%$ dos assediadores eram do gênero masculino e que ao menos $44,3 \%$ dos assédios podem ser classificados em assédio vertical, o que levanta debates acerca do risco adicional que mulheres podem ter no que concerne à ocorrência do assédio moral e à desigualdade de gêneros, sobretudo se considerada a pequena participação feminina em cargos gerenciais.

A pesquisa mostra ainda que, no tocante ao parecer do órgão julgador a respeito dos processos, $63,27 \%$ das causas não foram julgadas procedentes, sugerindo que as alegações estão mal fundamentadas, destituídas de provas concretas que as corroboram ou não se enquadram objetivamente na definição legal de assédio moral. Haja vista que em $64 \%$ dos casos julgados improcedentes as alegações do reclamante não foram ratificadas pela prova testemunhal colhida. Não bastasse, a entrevista com o representante do Sindicato dos Bancários de Belo Horizonte e Região indica que a maior parte dos trabalhadores bancários se sente amedrontada em prestar depoimentos que corroborem as alegações de assédio moral, dada a previsibilidade de represálias ou demissões.

As práticas abusivas de maior incidência, que justificaram a procedência do pedido indenizatório correspondente ao assédio moral, foram: sobrecarga de trabalho; exclusão/ 
isolamento proposital; imposição de obstáculos para o cumprimento de metas; submissão do trabalhador ao ócio de forma continuada e exigência de constante disponibilidade em prejuízo do descanso pessoal.

O resultado da pesquisa evidenciou a complexidade e a subjetividade do arbitramento da quantia indenizatória e as divergências doutrinárias e jurisprudenciais no que se refere à função da responsabilidade civil - considerada unicamente reparatória por uns e pedagógicapunitiva por outros.

A pesquisa das práticas de assédio moral sofridas por empregados de Instituições Financeiras de Minas Gerais, por meio da análise da jurisprudência do TRT-MG, reafirmou a necessidade de se buscar a responsabilização do agente agressor, com o intuito de inibir essas práticas e, por meio da decisão judicial, atribuir potencial de transformação da realidade social.

Ademais, a flexibilização normativa trazida pela reforma trabalhista, associada à inexistência, ou ineficiência, de mecanismos organizacionais de defesa contra o assédio; à debilidade dos sindicatos e à escassez de recursos do Ministério da Economia - por meio da Inspeção do Trabalho -, para fisscalizar e reprimir condutas irregulares nas relações laborais, podem favorecer a judicialização das querelas relacionadas ao assédio moral no ambiente de trabalho. Assim, a recorrência das práticas de assédio moral reforça o papel do Poder Judiciário como instância de repressão às condutas abusivas e reparação de danos.

O tema é amplo e merece ser estudado e complementado por trabalhos futuros que avaliem a evolução e as especificidades do assédio moral no setor bancário, bem como a aplicação da reforma trabalhista (Lei $\mathrm{n}^{\circ}$ 13.467/2017) pelo Judiciário Trabalhista de Minas Gerais no tocante às demandas de reparação extrapatrimonial por danos advindos do assédio moral no trabalho.

\section{REFERÊNCIAS}

ALKIMIN, M. A. Assédio moral na relação de trabalho. 2. ed. Curitiba: Juruá, 2009.

ANTUNES R. Descuidos do trabalho e trabalho dos cuidados. Revista Baiana de Enfermagem, v. 34, capa, 2020.

ANTUNES, R. Desenhando a nova morfologia do trabalho no Brasil. Estudos Avançados, São Paulo, v. 28, n. 81, p. 39-53, ago. 2014.

ANTUNES, R. O privilégio da servidão. 1. ed. São Paulo: Boitempo, 2018.

ANTUNES, R.; PRAUN, L. A sociedade dos adoecimentos no trabalho. Serviço Social \& Sociedade, n. 123, p. 407-427, 2015.

ARAÚJO, A. R. O assédio moral organizacional. São Paulo: LTr, 2007a.

ARAÚJO, A. R. Assédio moral organizacional. Revista do Tribunal Superior do Trabalho, Porto Alegre, v. 73, n. 2, p. 203-214, abr./jun. 2007b.

BARROS, R. C. L. G. Assédio moral: análise sob a luz dos aspectos configurativos e probatórios deste fenômeno social. Revista de Direito do Trabalho, São Paulo, v. 34, n. 129, p. 175-83, 2008 .

BATTISTELLI, B. M.; AMAZARRAY, M. R.; KOLLER, S. H. O assédio moral no trabalho na visão de operadores do direito. Psicol. Soc., Florianópolis, v. 23, n. 1, p. 35-45, abr. 2011. 
BESWICK, J.; GORE, J.; PALFERMAN, D. Bullying at work: areview of the literature. health and safety laboratory. Working Paper Series, v. 6, n. 4, 2006.

BRASIL. Decreto-lei no 900, de 29 de set. de 1969. Altera disposições do Decreto-lei número 200, de 25 de fevereiro de 1967, e dá outras providências. Diário Oficial da União, Brasília, DF, 29 set. 1969. Disponível em: http://www.planalto.gov.br/ccivil_03/Decreto-Lei/Del0900. htm. Acesso em: 16 out. 2019.

BRASIL. Decreto-lei n 13.467 , de 13 de julho de 2017. Diário Oficial da União, Brasília, DF, 13 jul. 2017a. Disponível em: http://www.planalto.gov.br/ccivil_03/_ato2015-2018/2017/ lei/113467.htm. Acesso em: 18 out. 2019.

BRASIL. Medida Provisória ${ }^{\circ}$ 808, de 14 de novembro de 2017. Diário Oficial da União, Brasília, DF, 14 nov. 2017b. Disponível em: http://www.planalto.gov.br/ccivil_03/_ato20152018/2017/Mpv/mpv808.htm\#art2. Acesso em: 18 out. 2019.

BRASIL. Ministério Público do Trabalho. Assédio moral em estabelecimentos bancários. Brasília, 2013.

BUSSINGUER, M. A. Liberdade e dignidade em Kant e o princípio da dignidade humana como fundamento do direito do trabalho. Revista de Direitos e Garantias Fundamentais, Vitória, n. 4, p. 121-146, jul./dez. 2008.

CAVALCANTE, J. Q. P.; JORGE NETO, F. F. O Direito do Trabalho e o assédio moral. Revista Jus Navigandi, Teresina, ano 10, n. 638, 7 abr. 2005.

DRUCK, G.; DUTRA, R.; SILVA, S. C. A contrarreforma neoliberal e a terceirização: a precarização como regra. Cad. CRH, Salvador, v. 32, n. 86, p. 289-306, ago. 2019.

EINARSEN, S. et al. The concept of bullying and harassment at work: the European tradition. In: EINARSEN et al. (Org.). Bullying and harassment in the workplace: developments in theory, research, and practice. London: Taylor \& Francis, 2011.

FINAZZI, M. A. Patologia da solidão: o suicídio de bancários no contexto da nova organização do trabalho. Dissertação (Mestrado) - Faculdade de Economia, Administração, Contabilidade e Ciências da Informação e Documentação, Universidade de Brasília, Brasília, 2009.

FRANCO, T.; DRUCK, G.; SELIGMANN-SILVA, E. As novas relações de trabalho, o desgaste mental do trabalhador e os transtornos mentais no trabalho precarizado. Rev. Bras. Saúde Ocup., São Paulo, v. 35, n. 122, p. 229-248, dez. 2010.

FREITAS, M. E. Cultura organizacional: grandes temas em debate. RAE eletrônica, v. 31, n. 1, p. 73-82, 1991.

FREITAS, M. E. Quem paga a conta do assédio moral no trabalho? Revista de Administração de Empresas, v. 6, n. 1, 2007.

FREITAS, M. E.; HELOANI, R.; BARRETO, M. Assédio moral no trabalho. São Paulo: Cengage Learning, 2008.

GIL, A. C. Métodos e técnicas de pesquisa social. 6. ed. Curitiba: Atlas, 2008.

GLINA, D. M. R.; SOBOLL, L. A. Intervenções em assédio moral no trabalho: uma revisão da literatura. Revista Brasileira de Saúde Ocupacional, v. 37, n. 126, 2012.

GUEDES, M. N. Terror psicológico no trabalho. 2. ed. São Paulo: Ltr, 2006. 
HARVEY, D. Condição Pós-Moderna: uma pesquisa sobre as origens da mudança cultural. 21. ed. São Paulo: Loyola, 2011.

HIRIGOYEN, M. F. Assédio moral: a violência perversa no cotidiano. Trad. de Maria Helena Kuhner. 3. ed. Rio de Janeiro: Bertrand Brasil, 2002.

LEONE, E. T.; TEIXEIRA, M. O. As mulheres no mercado de trabalho e na organização sindical. In: ENCONTRO NACIONAL DE ESTUDOS POPULACIONAIS, 17., Anais [...], Caxambu, 2016. p. 1-21.

LIBÓRIO, D. C. et al. (Orgs.). Direito Urbanístico em juízo: estudo de acórdãos do Tribunal de Justiça do Estado de São Paulo. São Paulo: IBDU, 2016.

MACIEL, R. H.; CAVALCANTE, R.; MATOS, T. G. R; RODRIGUES, S. Autorrelato de situações constrangedoras no trabalho e assédio moral nos bancários: uma fotografia. Psicologia \& Sociedade, v. 19, n. 3, 2007.

MOCCIA, M. H. P. P. S. Sociedade de economia mista. Enciclopédia jurídica da PUC-SP. 1. ed. São Paulo: Pontifícia Universidade Católica de São Paulo, 2017. Disponível em: https:// enciclopediajuridica.pucsp.br/verbete/227/edicao-1/sociedade-de-economia-mista. Acesso em: 15 dez. 2019.

PAROSKI, M. V. Assédio moral no trabalho. Revista Jus Navigandi, out. 2006.

REIS, S. S. Da insegurança jurídica à precarização das relações de emprego: os impactos da reforma trabalhista no Brasil. Revista de Direitos Fundamentais nas Relações do Trabalho, Sociais e Empresariais, v. 4, n. 1, p. 55-73, 2018.

RESENDE, S.; MENDES, A. M. A sobrevivência como estratégia para suportar o sofrimento no trabalho bancário. Rev. Psicol. Organ. Trab., Florianópolis, v. 4, n. 1, 2004.

SARLET, I. W.; MARINONI, L. G.; MITIDIERO, D. Curso de direito constitucional. São Paulo: Revista dos Tribunais, 2012.

SILVA, A. S. M. Assédio moral no ambiente de trabalho. Revista Jurídica Orbis, v. 2, n. 1, p. 99-120, 2011.

SINDICATO DOS BANCÁRIOS DE BRASÍLIA. Sindicato lança cartilha sobre saúde do bancário na Câmara, 2015.

SOARES, L. R.; VILLELA, W. V. O assédio moral na perspectiva de bancários. Revista Brasileira de Saúde Ocupacional, v. 37, n. 126, 2012.

SOBOLL, L. A. Assédio moral/organizacional: uma análise da organização do trabalho. São Paulo: Casa do Psicólogo, 2008.

SOBOLL, L. A. (Org.). Intervenções em assédio moral e organizacional. São Paulo: LTr, 2017.

SOBOLL, L. A.; MIARA, T.; MOSCALEWSKY, J. A questão da intencionalidade no assédio moral. Trabalho En(Cena), v. 2, n. 2, p. 3-17, 2017.

STADLER, D. F. Assédio moral: uma análise da teoria do abuso de direito aplicada ao poder do empregador. 1. ed. São Paulo: Ltr, 2008.

TRT-3. Processo $n^{\circ}$ 0010055-28.2017.5.03.0059. Relator: Luiz Antônio de Paula Iennaco. MINAS GERAIS, 2018a. Disponível em: https://www.jusbrasil.com.br/diarios/183152695/trt3-judiciario-22-03-2018-pg-2561. Acesso em: $1^{\mathrm{o}}$ jun. 2021. 
TRT-3. Recurso Ordinário 0010077-75.2014.5.03.0129. Relator: Marcelo Lamego Pertence. Minas Gerais, 2018b. Disponível em: Acesso em: $1^{\text {o }}$ jun. 2021.

TRT-3.RecursoOrdinário 0010902-85.2016.5.03.0052.Relatora:Juliana VignoliCordeiro.Minas Gerais, 2018c. Disponível em: https://as1.trt3.jus.br/juris/detalhe.htm?conversationId=4894. Acesso em: 8 fev. 2020.

TRT-3. Recurso Ordinário 0011270-48.2016.5.03.0132. Relator: Marcelo Lamego Pertence. Minas Gerais, 2018d. Disponível em: https://as1.trt3.jus.br/juris/detalhe. htm? conversationId=4894. Acesso em: 8 fev. 2020.

TRT-3. Recurso Ordinário 0011318-50.2015.5.03.0129. Relator: Jales Valadao Cardoso. Minas Gerais, 2018e. Disponível em: https://as1.trt3.jus.br/juris/detalhe.htm?conversationId=4894. Acesso em: 8 fev. 2020.

URABE, K. Y.; PADILHA, V. O assédio moral no trabalho em bancos e os desafios do sindicato dos bancários. FACEF Pesquisa-Desenvolvimento e Gestão, v. 19, n. 2, 2016.

WROLLI, R. Número de bancários doentes dispara em oito anos. Sindicado dos Bancários de São Paulo, 2019. Disponível em https://spbancarios.com.br/02/2019/numero-de-bancariosdoentes-dispara-em-oito-anos?utm_source $=$ Whatsapp\&utm_medium $=$ Whatsapp $\% 20$ Marketing. Acesso em: 20 mar. 2020. 